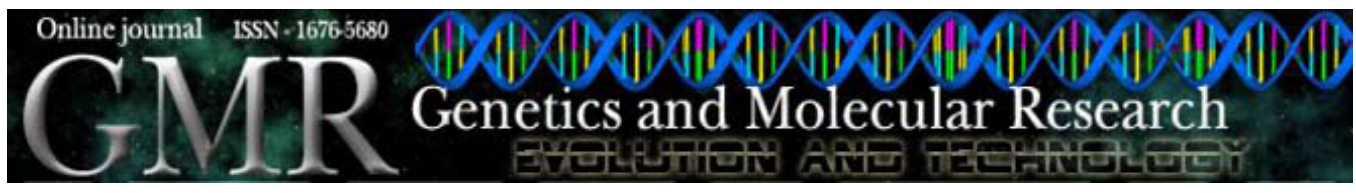

\title{
Screening of mutations in the $G C K$ gene in Jordanian maturity-onset diabetes of the young type 2 (MODY2) patients
}

R. Khalil ${ }^{1}$, F. Al-Sheyab ${ }^{2}$, E. Khamaiseh ${ }^{2}$, M.A. Halaweh ${ }^{1}$ and H.A. Abder-Rahman ${ }^{3}$

${ }^{1}$ Biotechnology and Genetic Engineering Department, Philadelphia University, Jordan

${ }^{2}$ Genetic Engineering and Biotechnology Department, Jordan University of Science and Technology, Jordan ${ }^{3}$ Forensic Medicine and Pathology Department, Faculty of Medicine, The University of Jordan, Jordan

Corresponding author: R. Khalil

E-mail: r_khalil@philadelphia.edu.jo

Genet. Mol. Res. 8 (2): 500-506 (2009)

Received February 6, 2009

Accepted March 13, 2009

Published May 5, 2009

\begin{abstract}
Maturity-onset diabetes of the young type 2 (MODY2) is a genetic form of diabetes mellitus caused by mutations in the glucokinase gene $(G C K)$. We assessed the frequency of $G C K$ gene mutations in Jordanian suspected MODY2 patients. We screened exons 7, 8 and 9, which are specific for pancreatic glucokinase, for mutations at positions 682A > G, p.T228A; 895G >C, p.G299R, and 1148C >A, p.S383X, respectively, in 250 subjects (100 patients suspected to have MODY2 and 150 healthy controls without family history of diabetes mellitus). We did not find any association of these mutations in Jordanian suspected MODY2 patients or in healthy controls, different from data on Caucasian Italian patients screened for the same mutations.
\end{abstract}

Key words: Glucokinase; MODY2; Mutation; Jordanian 


\section{INTRODUCTION}

Glucokinase is a member of the hexokinase family and plays a key role in glucose homeostasis as a glucose sensor in pancreatic $\beta$-cells. It catalyses the initial step in these pathways, ATP (adenosine triphosphate)-dependent phosphorylation to form glucose-6-phosphate (G-6-P) (Matschinsky et al., 1993). A reduction in $\beta$-cell glucokinase (GCK) amount or activity increases the glucose threshold for insulin secretion, causing typical fasting hyperglycemia (Byrne et al., 1994). GCK is expressed in pancreatic $\beta$-cells, hepatocytes and a variety of neural/neuroendocrine cells, including pancreatic $\alpha$-cells, L- and K-gut enterocytes and selected neurons (Schuit et al., 2001). Although GCK from pancreas, liver and brain are similar in kinetic activity and are coded by the same gene with 12 exons on chromosome 7 (7p15.3 - p15.1), their primary structures at the N-terminal end are different due to distinct splicing of the RNA transcript. The GCK enzyme contains 465 amino acids and exon 1 varies in diverse tissues due to the different promoter regions: the upstream promoter is functional in pancreas and brain, the downstream promoter is used only in liver (Stoffel et al., 1992; Gloyn, 2003).

In view of its crucial role in the regulation of glucose-stimulated insulin secretion, it is possible that mutations in the $G C K$ gene can cause both hyperglycemia and hypoglycemia. Genetic studies have shown that $G C K$ mutations are responsible for maturity-onset diabetes of the young type 2 (MODY2). MODY2 is a genetically and clinically heterogeneous form of diabetes mellitus, characterized by an early age at onset, a primary defect in $\beta$-cell function and an autosomal dominant inheritance (Fajans et al., 2001). Among the different types of MODY diabetes described thus far, each is due to a different gene mutation (HNF4A, GCK, HNF1A, IPF1, HNF1B, NEUROD1, CEL) (Raeder et al., 2006; Weedon and Frayling, 2007). The GCK MODY form is caused by mutations in the GCK gene. Thus far, about 200 GCK mutations have been reported and their frequency is higher in European Caucasians, particularly in those from France and Italy (Pinterova et al., 2007).

Missense mutations of $G C K$ represent the most frequent cause of MODY2; to date more than 200 mutations with distinct enzymatic characteristics have been found. These mutations were also detected in 5-6\% women with gestational diabetes (Ellard et al., 2000). Heterozygous activating missense $G C K$ mutations causing persistent hyperinsulinemic hypoglycemia of infancy and inactivating homozygous $G C K$ mutations leading to permanent neonatal diabetes mellitus are much less frequent (Gloyn, 2003).

Since there is no previous study focusing on the screening of the $G C K$ gene mutations in Jordan, this study was the first and established grounds for a preliminary screening aimed to assess the presence of the $G C K$ gene mutations in Jordanian MODY2 patients at the positions $682 \mathrm{~A}>\mathrm{G}$, p.T228A; $895 \mathrm{G}>$ C, p.G299R, and 1148C $>$ A, p.S383X and compared the results with a similar study previously conducted in a Caucasian Italian MODY2 population.

\section{MATERIAL AND METHODS}

\section{Subjects}

One hundred patients were recruited from the National Center for Diabetes, Endocrine and Genetic Diseases, King Hussein Clinical Hospital, University of Jordan Hospital and Islamic Hospital in Amman, King Abdullah University Hospital, Yarmok University Clinical Center, and Prince Basmah Hospital in Irbid, all in Jordan. 
The patients aged 18-27 years, 57 males and 43 females, whose clinical presentation was suggestive of MODY2 were selected for $G C K$ gene mutation detection. Inclusion criteria were: early onset (by 25 years) of diabetes, mild hyperglycemia, no autoimmune markers of type I diabetes, without obesity and positive family history of diabetes for at least two consecutive generations for most of the patients. No treatment was administered to the patients and no diabetes complications were evident up to diagnosis. A fasting blood sample was drawn from patients and from 100 unrelated controls, who were from the same geographical area, and used for the GCK molecular characterization. Informed consent, in accordance with guidelines of the above-mentioned centers and hospitals, was obtained from each patient or normal control subject.

\section{Clinical and biochemical examination}

We determined the clinical and biochemical parameters for each patient subject upon diagnosis (Table 1): age, age at diagnosis, fasting blood sugar, weight, height, family history of diabetes, body mass index, and glycosylated hemoglobin. The same parameters were determined for the control subjects.

\begin{tabular}{|c|c|c|}
\hline Parameter & $\begin{array}{l}\text { Patients } \\
(\mathrm{N}=100)\end{array}$ & $\begin{array}{l}\text { Controls } \\
(\mathrm{N}=150)\end{array}$ \\
\hline BMI $\left(\mathrm{kg} / \mathrm{m}^{2}\right)$ & $30.87 \pm 2.5$ & $24.1 \pm 0.4$ \\
\hline Age (years) & $25.4 \pm 0.5$ & $21.6 \pm 1.5$ \\
\hline Height $(\mathrm{cm})$ & $168.2 \pm 3.5$ & $168.2 \pm 2.7$ \\
\hline Weight (kg) & $76.5 \pm 5.3$ & $67.7 \pm 6.1$ \\
\hline Males & $57(57 \%)$ & $80(53.3 \%)$ \\
\hline Females & $43(43 \%)$ & $70(46.7 \%)$ \\
\hline FBS (mg/dL) & $178.5 \pm 5.8$ & $110 \pm 5.1$ \\
\hline HbAlc (\%) & $10.44 \pm 0.5$ & $5.07 \pm 0.58$ \\
\hline Age at diagnosis (years) & $30.0 \pm 2.0$ & - \\
\hline Positive family history & $70(70 \%)$ & $50(33.3 \%)$ \\
\hline Negative family history & $30(30 \%)$ & $100(66.7 \%)$ \\
\hline
\end{tabular}

$\mathrm{BMI}=$ body mass index; FBS $=$ fasting blood sugar; HbA1c $=$ glycosylated hemoglobin. Values are reported as means $\pm \mathrm{SD}$ or as number of subjects with percent in parentheses.

\section{DNA extraction}

Genomic DNA from patients and controls was extracted from whole blood plus EDTA using Wizard Genomic DNA Purification kit according to manufacturer recommendations (Promega, USA).

\section{Polymerase chain reaction analysis}

Detection of the mutations of exons 7, 8, and 9 of $G C K$ gene was performed by polymerase chain reaction (PCR), using previously reported primers (Matschinsky, 2002). The PCR mixture contained in a final volume of $25 \mu \mathrm{L}$ : $20 \mathrm{mM}$ of each primer, 1X PCR buffer (Promega), $10 \mathrm{mM}$ of each deoxynucleotide triphosphate (Promega, UK), 2.5 units Taq DNA polymerase (Applied Biosystems) and $200 \mathrm{ng}$ genomic DNA. Each PCR was performed in a thermocycler (BioRad, Italy, MJ-BioRad, Italy). 
The amplification conditions for each exon consisted of two initial cycles at $94^{\circ} \mathrm{C}$ for $30 \mathrm{~s}, 52^{\circ} \mathrm{C}$ for $1 \mathrm{~min}$, and $72^{\circ} \mathrm{C}$ for $1 \mathrm{~min}$, followed by 30 cycles at $94^{\circ} \mathrm{C}$ for $30 \mathrm{~s}, 55^{\circ} \mathrm{C}$ for 30 $\mathrm{s}$, and $72^{\circ} \mathrm{C}$ for $30 \mathrm{~s}$, followed by $5 \mathrm{~min}$ at $72^{\circ} \mathrm{C}$, and ending at $4^{\circ} \mathrm{C}$.

The PCR products were evaluated by agarose gel electrophoresis at $100 \mathrm{~V}$ for $30 \mathrm{~min}$.

The primer list and expected size of PCR amplification products are shown in Table 2.

Table 2. Primers used for amplification of exons 7, 8 and 9 of $G C K$ gene and the expected length of PCR products.

\begin{tabular}{lccc}
\hline Nucleotide changes & Exon & Amino acid changes & Restriction enzyme \\
\hline $682 \mathrm{~A}>\mathrm{G}$ & 7 & Thr228Ala & $B s t \mathrm{UI}$ \\
$772 \mathrm{G}>\mathrm{T}$ & 8 & Gly299Arg & $H h a \mathrm{I}$ \\
$1148 \mathrm{C}>\mathrm{A}$ & 9 & Ser383Tyr & $B f a \mathrm{I}$ \\
\hline
\end{tabular}

Oligonucleotides were synthesized by Alpha DNA, Canada.

\section{Restriction fragment length polymorphism}

To screen the missense mutations at positions T228A and G299R and a nonsense mutation S383X in exons 7, 8, and 9, respectively, the amplified PCR products for exons 7, 8, and 9 were cleaved using $B s t \mathrm{UI}, H h a \mathrm{I}$ and $B f a \mathrm{I}$ restriction endonucleases, respectively. The PCR products were treated with 5 units of restriction endonuclease. The mixture was incubated at $37^{\circ} \mathrm{C}$ for $24 \mathrm{~h}$, and then electrophoresed on 2-3\% agarose gels at $100 \mathrm{~V}$ for $30 \mathrm{~min}$. The positive controls for the mutations were gifts from Dr. Vilma Mantovani (Centro Ricerca Biomedica Applicata, Bologna, Italy).

The description of restriction recognition sites, the lengths of the PCR products, restriction products, and screened mutant amino changes by each endonuclease are shown in Table 3 and Table 4 , respectively.

\begin{tabular}{|c|c|c|c|}
\hline$G C K$ gene & & Primer sequence & Size of PCR product (bp) \\
\hline Exon7 & $\mathrm{F}$ & 5'- TGCAGCTCTCGCTGACAGTCC -3' & 287 \\
\hline Exon7 & $\mathrm{R}$ & 5'- CTCCCATCTGCCGCTGCACC -3' & \\
\hline Exon8 & $\mathrm{F}$ & 5'- CGTGCCTGCTGATGTAATGG -3' & 268 \\
\hline Exon8 & $\mathrm{R}$ & 5'- GCCCTGAGACCAAGTCTGC -3' & \\
\hline Exon9 & $\mathrm{F}$ & 5'- CTGTCGGAGCGACACTCAG - -3' & 410 \\
\hline Exon9 & $\mathrm{R}$ & 5'- CCCCCAAATCTAGGCCAAGG -3' & \\
\hline
\end{tabular}

\begin{tabular}{|c|c|c|c|c|}
\hline \multirow[t]{2}{*}{$G C K$ gene } & \multirow[t]{2}{*}{ Restriction enzyme } & \multirow[t]{2}{*}{ Recognition site } & \multicolumn{2}{|c|}{ RFLP resultant fragment (bp) } \\
\hline & & & Normal & Mutant \\
\hline Exon 7 & $B s t \mathrm{UI}$ & $\begin{array}{l}5^{\prime}, \ldots \mathrm{CG} \mathbf{\nabla C G} \ldots 3^{\prime}, \\
3^{\prime} \ldots \ldots \mathrm{GC} \boldsymbol{\mathrm { GC }} \ldots 5^{\prime}\end{array}$ & $\begin{array}{c}\text { (287) } \\
\text { No cutting }\end{array}$ & $\begin{array}{r}245 \\
42\end{array}$ \\
\hline Exon 8 & $H h a \mathrm{I}$ & $\begin{array}{l}5^{\prime}, \ldots \mathrm{GCG} \mathbf{\nabla C} \ldots 3^{\prime}, \\
3^{\prime} \ldots \ldots \mathrm{\triangle} \mathbf{\mathrm { GCG }} \ldots 5,\end{array}$ & $\begin{array}{c}(268) \\
116 \mathrm{bp} \\
152 \mathrm{bp}\end{array}$ & No cutting \\
\hline Exon 9 & $B f a \mathrm{I}$ & $\begin{array}{l}5^{\prime}, \ldots \mathrm{C} \nabla \mathrm{TAG} \ldots 3^{\prime} \\
3^{\prime} \ldots \ldots \text { GAT } \nabla \mathrm{C} \ldots 5^{\prime}\end{array}$ & $\begin{array}{c}(410) \\
398 \\
12\end{array}$ & $\begin{array}{r}323 \\
75 \\
12\end{array}$ \\
\hline
\end{tabular}




\section{RESULTS}

The PCR products were screened for the presence of Thr228Ala missense mutation in exon 7 of the $G C K$ gene where the A changes to $\mathrm{G}$ at nucleotide 682 for the restriction transition profile for the $B s t \mathrm{UI}$ restriction enzyme. The wild-type allele is resistant to digestion by $B s t \mathrm{UI}$ while the mutant allele produces fragments of 245 and $42 \mathrm{bp}$.

An HhaI restriction enzyme is used to genotype the Gly299Arg missense mutation in exon 8 of the $G C K$ gene in which $\mathrm{G}$ changes to T at nucleotide 772. An HhaI restriction digestion in the wild-type allele yields two fragments of 116 and $152 \mathrm{bp}$, while the mutant allele lacks the $H$ haI recognition site.

The detection of the Ser383Tyr nonsense mutation at nucleotide 1148, where C changes to A was by $B f a \mathrm{I}$ restriction enzyme. A $B f a$ I digestion of the mutant allele yields three fragments of 323,75 , and $12 \mathrm{bp}$, while the wild-type allele yields two fragments of 398 and $12 \mathrm{bp}$.

The screening of the GCK gene mutations among the Jordanian MODY2 suspect and healthy control subjects using PCR-restriction fragment length polymorphism analysis showed no observed mutants in both MODY2 and healthy control subjects. The PCR products for all the amplified products followed the same pattern of restriction action in both patients and controls. Therefore, no observed Thr228Ala, Gly299Arg and Ser383Tyr mutations were detected in the MODY2 diabetics or normal control subjects. Thus, the results are different from a previous study that detected the presence of the above-mentioned mutations in Caucasian Italians from the Oxford region in UK MODY2 patients.

\section{DISCUSSION}

MODY is a relatively rare form of diabetes mellitus, and some studies suggest that it may not be so uncommon as hypothesized and that $2-5 \%$ of patients with diabetes mellitus type 2 may in fact have MODY (Ledermann, 1995).

Recent data support the finding that MODY is prevalent in approximately $1-2 \%$ of diabetic patients in Europe (Owen and Hattersley, 2001). MODY2 and MODY3 represent the most common forms of MODY in Europe. The relative prevalence of MODY2 among all MODY patients varies greatly in studies from different populations: from $46-56 \%$ in France (Froguel et al., 1993; Velho et al., 1997), 41-61\% in Italy (Massa et al., 2001; Mantovani et al., 2003), 25-41\% in Spain (Costa et al., 2000; Barrio et al., 2002), and 31\% in the Czech Republic (Pruhova et al., 2003) to 11-20\% in the UK (Thomson et al., 2003), 10\% in Denmark (Johansen et al., 2005), 8\% in Germany (Lindner et al., 1999), and 3.5\% in Scandinavia (Lehto et al., 1999). The clinical features of MODY2 are usually mild, and diagnosis is often accidental (Hattersley, 2005). MODY2 is caused by mutations in the $G C K$ gene.

The identification of a $G C K$ mutation in subjects whose clinical phenotype is suggestive of MODY usually distinguishes patients with a benign prognosis (GCK MODY) from those with severe hyperglycemia (other MODY forms) because the diagnosis cannot always be made on clinical grounds alone. Moreover, according to the variations in the prevalence risk of MODY2 among different populations, we decided to screen $G C K$ gene mutations in Jordanian MODY2 populations and to determine racial differences. Furthermore, a recent study revealed an increase in the prevalence of diabetes mellitus in Jordan over 10 years (Ajlouni et al., 2008). 
In this study, we did not find positive cases for the $G C K$ gene mutation at positions $682 \mathrm{~A}>\mathrm{G}$, p.T228A, 895G $>$ C, p.G299R and 1148C $>$ A, p.S383X, respectively, in 100 patients with suspect MODY2 in comparison to the positive control DNA samples for those mutations in Italian MODY2 patients, so there was no difference between MODY2 and healthy control subjects.

However, previous studies found that the $G C K$ gene mutations occur in $6 \%$ of cases in Italian and Norwegian populations, and between 8 and 56\% in southern European countries (Shehadeh et al., 2005; Stern et al., 2007; Sagen et al., 2008).

Thus, this preliminary study cannot exclude the possibility that the $G C K$ gene is a risk gene in the pathogenesis of MODY2 in the Jordanian populations. Therefore, wide spectrum investigations of GCK gene mutations in MODY2 Jordanian populations and variants are strongly recommended and worthwhile.

In conclusion, molecular screening is useful in the diagnosis of MODY because it allows the physician to confirm the diagnosis and to predict the severity of the mutation and prognosis as well as the clinical course of the patient.

\section{REFERENCES}

Ajlouni K, Khader YS, Batieha A, Ajlouni H, et al. (2008). An increase in prevalence of diabetes mellitus in Jordan over 10 years. J. Diabetes Complications 22: 317-324.

Barrio R, Bellanne-Chantelot C, Moreno JC, Morel V, et al. (2002). Nine novel mutations in maturity-onset diabetes of the young (MODY) candidate genes in 22 Spanish families. J. Clin. Endocrinol. Metab. 87: 2532-2539.

Byrne MM, Sturis J, Clement K, Vionnet N, et al. (1994). Insulin secretory abnormalities in subjects with hyperglycemia due to glucokinase mutations. J. Clin. Invest. 93: 1120-1130.

Costa A, Bescós M, Velho G, Chêvre J, et al. (2000). Genetic and clinical characterisation of maturity-onset diabetes of the young in Spanish families. Eur. J. Endocrinol. 142: 380-386.

Ellard S, Beards F, Allen LI, Shepherd M, et al. (2000). A high prevalence of glucokinase mutations in gestational diabetic subjects selected by clinical criteria. Diabetologia 43: 250-253.

Fajans SS, Bell GI and Polonsky KS (2001). Molecular mechanisms and clinical pathophysiology of maturity-onset diabetes of the young. N. Engl. J. Med. 345: 971-980.

Froguel P, Zouali H, Vionnet N, Velho G, et al. (1993). Familial hyperglycemia due to mutations in glucokinase. Definition of a subtype of Diabetes mellitus. N. Engl. J. Med. 328: 697-702.

Gloyn AL (2003). Glucokinase (GCK) mutations in hyper- and hypoglycemia: maturity-onset diabetes of the young, permanent neonatal diabetes, and hyperinsulinemia of infancy. Hum. Mutat. 22: 353-362.

Hattersley AT (2005). Molecular genetics goes to the diabetes clinic. Clin. Med. 5: 476-481.

Johansen A, Ek J, Mortensen HB, Pedersen O, et al. (2005). Half of clinically defined maturity-onset diabetes of the young patients in Denmark do not have mutations in HNF4A, GCK, and TCF1. J. Clin. Endocrinol. Metab. 90: 4607-4614.

Ledermann HM (1995). Is maturity onset diabetes at young age (MODY) more common in Europe than previously assumed? Lancet 345: 648.

Lehto M, Wipemo C, Ivarsson SA, Lindgren C, et al. (1999). High frequency of mutations in MODY and mitochondrial genes in Scandinavian patients with familial early-onset diabetes. Diabetologia 42: 1131-1137.

Lindner TH, Cockburn BN and Bell GI (1999). Molecular genetics of MODY in Germany. Diabetologia 42: 121-123.

Mantovani V, Salardi S, Cerreta V, Bastia D, et al. (2003). Identification of eight novel glucokinase mutations in Italian children with maturity-onset diabetes of the young. Hum. Mutat. 22: 338.

Massa O, Meschi F, Cuesta-Munoz A, Caumo A, et al. (2001). High prevalence of glucokinase mutations in Italian children with MODY. Influence on glucose tolerance, first-phase insulin response, insulin sensitivity and BMI. Diabetes Study Group of the Italian Society of Paediatric Endocrinology and Diabetes (SIEDP). Diabetologia 44: 898-905.

Matschinsky F, Liang Y, Kesavan P, Wang L, et al. (1993). Glucokinase as pancreatic beta cell glucose sensor and diabetes gene. J. Clin. Invest. 92: 2092-2098.

Matschinsky FM (2002). Regulation of pancreatic beta-cell glucokinase: from basics to therapeutics. Diabetes 51 (Suppl 3): S394-S404.

Owen K and Hattersley AT (2001). Maturity-onset diabetes of the young: from clinical description to molecular genetic 
characterization. Best Pract. Res. Clin. Endocrinol. Metab. 15: 309-323.

Pinterova D, Ek J, Kolostova K, Pruhova S, et al. (2007). Six novel mutations in the GCK gene in MODY patients. Clin. Genet. 71: 95-96.

Pruhova S, Ek J, Lebl J, Šumnik Z, et al. (2003). Genetic epidemiology of MODY in the Czech republic: new mutations in the MODY genes HNF-4alpha, GCK and HNF-1alpha. Diabetologia 46: 291-295.

Raeder H, Johansson S, Holm PI, Haldorsen IS, et al. (2006). Mutations in the CEL VNTR cause a syndrome of diabetes and pancreatic exocrine dysfunction. Nat. Genet. 38: 54-62.

Sagen JV, Bjorkhaug L, Molnes J, Raeder H, et al. (2008). Diagnostic screening of MODY2/GCK mutations in the Norwegian MODY Registry. Pediatr. Diabetes 9: 442-449.

Schuit FC, Huypens P, Heimberg H and Pipeleers DG (2001). Glucose sensing in pancreatic beta-cells: a model for the study of other glucose-regulated cells in gut, pancreas, and hypothalamus. Diabetes 50: 1-11.

Shehadeh N, Bakri D, Njolstad PR and Gershoni-Baruch R (2005). Clinical characteristics of mutation carriers in a large family with glucokinase diabetes (MODY2). Diabet. Med. 22: 994-998.

Stern E, Strihan C, Potievsky O, Nimri R, et al. (2007). Four novel mutations, including the first gross deletion in TCF1, identified in HNF-4alpha, GCK and TCF1 in patients with MODY in Israel. J. Pediatr. Endocrinol. Metab. 20: 909-921.

Stoffel M, Froguel P, Takeda J, Zouali H, et al. (1992). Human glucokinase gene: isolation, characterization, and identification of two missense mutations linked to early-onset non-insulin-dependent (type 2) diabetes mellitus. Proc. Natl. Acad. Sci. U. S. A. 89: 7698-7702.

Thomson KL, Gloyn AL, Colclough K, Batten M, et al. (2003). Identification of 21 novel glucokinase (GCK) mutations in UK and European Caucasians with maturity-onset diabetes of the young (MODY). Hum. Mutat. 22: 417.

Velho G, Blanché H, Vaxillaire M, Bellanné-Chantelot C, et al. (1997). Identification of 14 new glucokinase mutations and description of the clinical profile of 42 MODY-2 families. Diabetologia 40: 217-224.

Weedon MN and Frayling TM (2007). Insights on pathogenesis of type 2 diabetes from MODY genetics. Curr. Diab. Rep. 7: 131-138. 